Article

\title{
The Effect of Internet Searches on Afforestation: The Case of a Green Search Engine
}

\author{
Pedro Palos-Sanchez 1,2,*(i) and Jose Ramon Saura ${ }^{3, *(1)}$ \\ 1 Department of Business Management, University of Extremadura, Av. Universidad, s/n, \\ 10003 Cáceres, Spain \\ 2 Department of Business Organization, Marketing and Market Research, International University of La Rioja, \\ Av. de la Paz, 137, 26006 Logroño, Spain \\ 3 Department of Business and Economics, Rey Juan Carlos University, Paseo Artilleros s/n, \\ 28027 Madrid, Spain \\ * Correspondence: ppalos@unex.es (P.P.-S.); joseramon.saura@urjc.es (J.R.S.); \\ Tel.: +34-927-257-480 (P.P.-S.); +34-91-488-80-11 (J.R.S.)
}

Received: 17 November 2017; Accepted: 19 January 2018; Published: 23 January 2018

\begin{abstract}
Ecosia is an Internet search engine that plants trees with the income obtained from advertising. This study explored the factors that affect the adoption of Ecosia.org from the perspective of technology adoption and trust. This was done by using the Unified Theory of Acceptance and Use of Technology (UTAUT2) and then analyzing the results with PLS-SEM (Partial Least Squares-Structural Equation Modeling). Subsequently, a survey was conducted with a structured questionnaire on search engines, which yielded the following results: (1) the idea of a company helping to mitigate the effects of climate change by planting trees is well received by Internet users. However, few people accept the idea of changing their habits from using traditional search engines; (2) Ecosia is a search engine believed to have higher compatibility rates, and needing less hardware resources, and (3) ecological marketing is an appropriate and future strategy that can increase the intention to use a technological product. Based on the results obtained, this study shows that a search engine or other service provided by the Internet, which can be audited (visits, searches, files, etc.), can also contribute to curb the effects of deforestation and climate change. In addition, companies, and especially technological start-ups, are advised to take into account that users feel better using these tools. Finally, this study urges foundations and non-governmental organizations to fight against the effects of deforestation by supporting these initiatives. The study also urges companies to support technological services, and follow the behavior of Ecosia.org in order to positively influence user satisfaction by using ecological marketing strategies.
\end{abstract}

Keywords: search internet; Ecosia; google; UTAUT2 model; ecological marketing; PLS

\section{Introduction}

In the last decade, organizations have quickly adapted to the Internet, social networks, and search engines. The appearance of Web 2.0 has allowed users to design, create, and produce content and activities on the Internet [1].

These new forms of online expression have transformed and changed the ideas of users and organizations so that they can achieve their goals. Therefore, Web 2.0, Social Media, and search engines have transformed how users obtain information about the topics that interest them on the Internet [2].

With the increase in the volume of content on the Internet in recent years and the search for information using search engines, the quality and speed of information sources has increased its potential. To achieve this, search engines have increased their efforts to apply quality filters that group 
search results into relevant sources, and respond to the queries made by users. Search engines are widely used to measure the interest that people have in a certain topic.

In this way, numerous investigations have evaluated the effectiveness of search engines as sources for obtaining information. Some of these investigations have analyzed the sustainability of search engines based on linguistic factors. In the research study by Allen and Seaman [3], the authors measured the correlations between the impressions users had of a search engine and the number of queries made with it. In the investigations by Allen and Seaman [3] and Bankole et al. [4], analyses were conducted that compared the number of times a search engine showed results to the number of web pages indexed. In addition, the research of Baptista and Oliveira [5] analyzed the opinions made on a search engine over a limited period of time.

The research of Batet and Sánchez [6] was concerned with evaluating search engines using the frequency and probability of the queries made as variables, and then identifying the best search engine using Linguistic Research.

The research of Bollegala et al. [7] was focused on the importance of the types of search engines that support social work from the point of view of technology and information. The research by NetMarket [8] explained Ecosia's social business model by studying global pollution changes compared to the trees planted by the search engine. The research of Venkatesh et al. and Shaikh and Karjaluoto $[9,10]$ considered the impact that search engines have on the development of Green Business Models by analyzing the Ecosia search engine with the case study methodology. We must emphasize that these investigations were carried out on search engines such as: Google, Yahoo, or Bing [11]. According to the research by NetMarket [8], the market share of search engines is distributed globally, as can be seen in Table 1, which shows data from year 2016.

Table 1. Search engines in order of Market Share.

\begin{tabular}{cc}
\hline Search Engines & Total Market Share \\
\hline Google-Global & $78.78 \%$ \\
Bing & $7.65 \%$ \\
Baidu & $7.33 \%$ \\
Yahoo-Global & $4.70 \%$ \\
Ask-Global & $0.16 \%$ \\
AOL-Global & $0.04 \%$ \\
Excite-Global & $0.02 \%$ \\
\hline
\end{tabular}

The search engine that obtains the highest global market share is Google, with a total of $78.78 \%$. The search engine that appears with the second highest market share is Bing, with $7.65 \%$ of searches around the world. In third and fourth place appear Baidu (the Chinese search engine) and Yahoo, with a total market share of $7.33 \%$ and $4.70 \%$, respectively. The number of global searches performed daily, if we take into account all search engines, is 6,586,013,574. If we look at the results of the Similar Web Search Report (2017), the sponsored search results, known as SEM (Search Engine Marketing) strategy or paid search, get $5 \%$ of the traffic and clicks, while $95 \%$ of traffic and clicks are on organic search results, which are known as SEO (Search Engine Optimization). Since 2008, there have been many initiatives which have developed search engines with socially responsible objectives.

This work has been structured as follows: The first section, called Literature Review, reviews the background of ecological marketing and, more specifically, the case of Ecosia.org. Likewise, this section reviews studies of the adoption of search engine technology on the Internet. In the second section, the UTAUT2 framework (Unified theory of acceptance and use of technology) [12] is proposed as the technology adoption theory selected to understand the adoption model of Ecosia.org. Also, Trust was proposed as the external variable for the variables in this theory, given the specific functionalities of Ecosia.org. Finally, this section lists the eleven hypotheses proposed in the study.

In the third section, the selected methodology is detailed, which in our case was the survey technique. This quantitative method allowed us to propose a questionnaire (Appendix A) that was 
given to a sample $(n=445)$ of regular users of search engines on the Internet. The fourth section carries out an analysis of the results by using PLS-SEM (Partial Least Squares-Structural Equation Modeling). Finally, the last section concludes with a summary of the most important findings. This research seeks to clarify whether search engine users are willing to use a search engine like Ecosia, knowing that it helps to mitigate climate change, favors the planting of trees, and therefore deforestation, or if, on the contrary, these benefits for planet Earth are not enough to change the search engine that they use daily.

\section{Literature Review}

\subsection{The Search Engine Ecosystem}

There have been important changes in the information management ecosystem in recent years. This means that nowadays there is a large variety of techniques and tools for consumers or Internet users to obtain information in digital environments. When a query is made on a search engine, the best possible truthful and up-to-date results are made available to the users. The result of a query, known as "ranking of results" or SEPRs (Search Engine Pages Results), is automatically developed by the search engine, based on hundreds of parameters that the algorithm takes into account to rate each website according to the search that has been made, which offers only relevant results.

In these search results, search engines show sponsored ads known as SEM (Search Engine Marketing) that are used to generate revenue. Search engines are the first source of information for users according to the research carried out by Shaikh and Karjaluoto, Jayaram et al., Chaffey and Patron, and Saura et al. [10-13], in which they study user behavior on these search engines. The results displayed by the search engines do not all generate income when the user clicks on them. However, if a sponsored result receives a click, the search engine obtains a commission from the CPC (Cost per Click) advertisement owner. In general, these sponsored search results are the main source of income for search engines [14-16].

The results of the searches offered by the search engines show a warning with the word "Ads" advising the consumer that they are commercial search results for advertising purposes and are those corresponding to the results of "Paid Search" that generate income for the search engines [13,14].

The work of Martínez-Sanahuja and Sánchez [17] identifies the main search engines that exist in the market and that use this technology to generate income with searches made by users. Table 2 shows the search engines in terms of their relevance according to the work of Schmidt et al. [18].

Table 2. Use of Search Engines and Paid Search.

\begin{tabular}{|c|c|c|}
\hline Search Engine & Year & Description \\
\hline AOL Search & 2005 & AOL Inc. is an American mass media corporation that develops and invests in brands and web sites. \\
\hline Bing & 2009 & $\begin{array}{c}\text { Bing is a web search engine owned and operated by Microsoft. The service has its origins in Microsoft's previous } \\
\text { search engines: MSN Search, Windows Live Search, and, later, Live Search. }\end{array}$ \\
\hline Ecosia & 2009 & $\begin{array}{c}\text { Ecosia is a web search engine based in Berlin, Germany. Ecosia's search results are powered by Bing, but the actual } \\
\text { hit count differs from those of Bing. }\end{array}$ \\
\hline Entireweb & 2000 & Entireweb.com is a search engine launched in 2000 by Entireweb Sweden AB. \\
\hline Gigablast & 2000 & Gigablast is a small independent web search engine based in New Mexico. \\
\hline Google & 1998 & Google Search is the most-used search engine on the World Wide Web. It is the most used search engine worldwide. \\
\hline HotBot & 1996 & HotBot is a web search engine currently owned by Lycos. It was launched in May 1996 by Wired magazine. \\
\hline Lycos & 1994 & Lycos, Inc. is a search engine and web portal established in 1994, a spin-off from Carnegie Mellon University. \\
\hline Yahoo! Search & 1995 & Yahoo! Search is a web search engine owned by Yahoo. \\
\hline
\end{tabular}




\subsection{Ecosia.org: The Search Engine that Plants Trees}

Ecosia is a Green Search Engine that donates at least $80 \%$ of its advertising benefits to WWF (Word Wide Fund for nature) programs for reforestation. These promoted results are known in the company as Ecolinks. In Nils research, an in-depth description of this search engine was made. The Ecosia search engine does not provide its own search engine due to financial limitations, but works with the Bing search engine technology. Revenue is generated by the clicks that users make on the promoted ads that appear in the search results.

Eighty percent $(80 \%)$ of the income generated by clicks on these ads is donated to programs for reforestation [19]. The remaining $20 \%$ is used to pay for necessary costs such as salaries, servers, domains, or marketing. According to the research of Schmidt et al. [18], the CEO (Chief Executive Officer) of the company has a salary lower than $1000 €$. According to the latest company data of July 2017, Ecosia has already planted 11.5 million trees and has an average of 202,323 daily active users that perform an average of 500,000 searches per day. This translates into 0.5 Euro cents per search and click on Ecolinks. In Table 3 an overview of the company can be seen:

Table 3. Overview of Ecosia.

\begin{tabular}{cc}
\hline Ecosia.org & Description \\
\hline Foundation & 2009 \\
Headquarters & Wittenberg/Germany \\
Industry & Internet, Social Business \\
Products and Services & Internet Search Services \\
Short Description & Independent Non-Profit Website \\
Partners & Yahoo, Bing, WWF (World Wide Fund for Nature) \\
URL & Ecosia.org \\
Revenue (estimated 2016) & Approx. EUR€1.7 M \\
Employees & 3 core employees, 10 to 15 volunteers \\
IT infrastructure & 1 server, use of the external infrastructure from Yahoo and Bing \\
\hline
\end{tabular}

Ecosia has set a very clear goal, which is to achieve one billion planted trees by the year 2020 . According to the research on Ecosia org in 2010, Ecosia manages to maintain its financial structure and costs because it does not have its own search engine and therefore has no hardware to maintain; the company considers its search engine as a personal contribution to the environment and society, instead of a project for investment based on profitability, and marketing is carried out to increase the social awareness of search engine users [15,18].

The projects that Ecosia finances are for planting trees, mainly in the African and Brazilian continents, and therefore we can say that Ecosia is an example of a social business model in the search engine market [19].

Projects for planting trees were chosen for the following reasons. Trees provide a cool climate and absorb $\mathrm{CO}_{2}$, one of the main causes of climate change. Likewise, large forests can even create clouds that in turn reflect sunlight and cool our planet, thus helping to mitigate the effects of global warming. Biodiversity is also increased by the forests created with the trees, as they produce diverse, sustainable wildlife systems for plants and animals to live in [18,19].

In Figure 1, we can see the number of trees planted per year by Ecosia.

Trees help to protect land and soil from erosion, and also to create productive and fertile land. In addition, trees generate clean air and provide the oxygen that we need to breathe. Trees also clean the air by absorbing polluting gases and filtering toxic particles. Trees are additionally a source of healthy foods and other products which can be harvested sustainably.

The livelihoods of 1.6 billion people around the world depends on these products. Finally, trees provide water security, as forests regulate water cycles and prevent floods, create humid microclimates, and increase groundwater levels. 


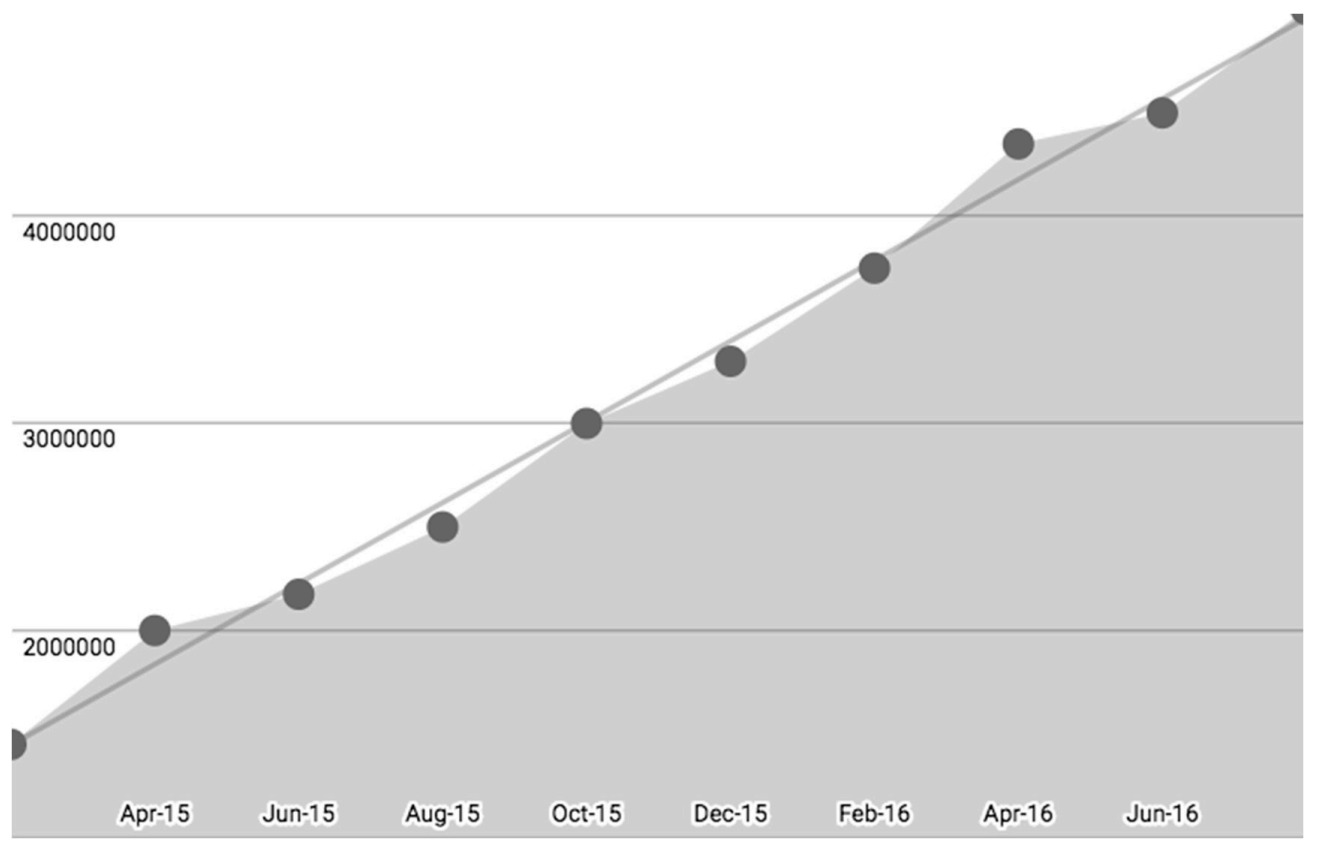

Figure 1. Yearly tree planting from 2015 to 2017 (Source: Authors).

These are the reasons that the Ecosia search engine gives as the basis for its business model of planting trees $[18,20]$.

In addition, it is important to identify the parts of the world where these plantation projects are being carried out in order to assess their biodiversity.

To do this, the search engine provides the following information about the projects being carried out in the different areas of the world. In Figure 2, the geographical areas with Ecosia projects can be seen.

In Table 4, the geographical areas and the relevant objectives of tree planting by Ecosia are explained [17-19].

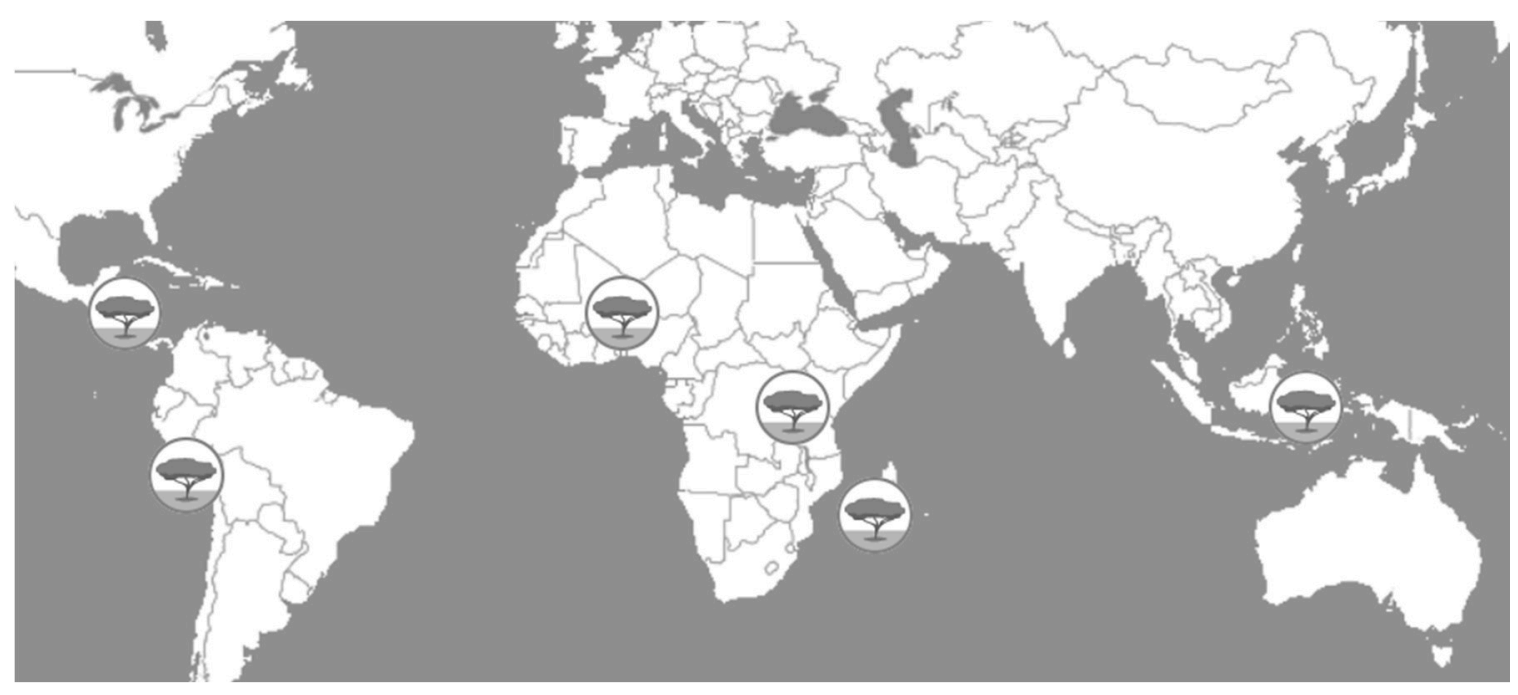

Figure 2. Ecosia projects identified geographically. 
Table 4. Geographical area and objectives of Ecosia.

\begin{tabular}{|c|c|c|c|}
\hline Project & Country & Partners & Commitment \\
\hline $\begin{array}{l}\text { Mountain } \\
\text { Reforestation }\end{array}$ & $\begin{array}{l}\text { Usambara, } \\
\text { Tanzania }\end{array}$ & $\begin{array}{l}\text { Friends of the } \\
\text { Usambara Society }\end{array}$ & $\begin{array}{l}\text { It aims to conserve this vulnerable ecosystem with an } \\
\text { ingenious combination of agroforestry, ecotourism, and the } \\
\text { recovery of tropical forests, as it is one of the } 36 \text { critical points } \\
\text { of biodiversity on our planet. }\end{array}$ \\
\hline $\begin{array}{l}\text { Geographic } \\
\text { Reforestation }\end{array}$ & San Martín, Perú & Pur Project & $\begin{array}{l}\text { Work with local coffee and cocoa cooperatives to reforest the } \\
\text { site and create new revenue models. In this way, small } \\
\text { farmers plant trees and are trained in agroforestry, forest } \\
\text { management, and sustainable farming. This area was heavily } \\
\text { deforested in the 1980s. }\end{array}$ \\
\hline $\begin{array}{l}\text { Volcano slopes } \\
\text { Reforestation }\end{array}$ & $\begin{array}{c}\text { Nicaraguan } \\
\text { Pacific, Zona of } \\
\text { León, Nicaragua }\end{array}$ & Día Foundation & $\begin{array}{l}\text { The objective is to restore these volcanic slopes to stop further } \\
\text { erosion of the soil. With a landscaping approach, this project } \\
\text { will help to protect nature, recover water sources, and provide } \\
\text { farmers with a more sustainable alternative livelihood model. }\end{array}$ \\
\hline $\begin{array}{c}\text { Tropical } \\
\text { Rainforest } \\
\text { Recuperation }\end{array}$ & Madagascar & $\begin{array}{l}\text { Eden } \\
\text { Reforestation } \\
\text { Projects }\end{array}$ & $\begin{array}{l}\text { To restore the forests, and thus support the return of fauna } \\
\text { and stop the erosion of the soil. Most of the trees planted are } \\
\text { mangroves, which grow in salt water and are an excellent area } \\
\text { for fish reproduction. Mangroves are also very good at } \\
\text { absorbing carbon from the air. This area is a key point of } \\
\text { biodiversity and has already lost } 90 \% \text { of its forests. }\end{array}$ \\
\hline $\begin{array}{l}\text { Burkina Faso } \\
\text { desert }\end{array}$ & $\begin{array}{l}\text { Sahel Region, } \\
\text { Burkina Faso }\end{array}$ & $\begin{array}{c}\text { OZG } \\
\text { (Entrepreneurs } \\
\text { Without Borders) }\end{array}$ & $\begin{array}{l}\text { Trees are being planted to slow the advance of the desert and } \\
\text { make the land fertile again. With the help of tractors, water } \\
\text { basins are excavated in the dry soil. Later, the countrymen fill } \\
\text { the basins with seeds, which germinate during the rainy } \\
\text { seasons. These trees grow strong and, gradually, bring back } \\
\text { the opportunities for life and the economy to the region. }\end{array}$ \\
\hline $\begin{array}{l}\text { Palm Oil } \\
\text { Alternatives }\end{array}$ & $\begin{array}{l}\text { Isla de Borneo, } \\
\text { Indonesia }\end{array}$ & $\begin{array}{l}\text { Gunung Saran } \\
\text { Lester, Masarang }\end{array}$ & $\begin{array}{l}\text { Ecosia contributes to the successful story of a nearby village, } \\
\text { where conservationist Willie Smits and his Masarang } \\
\text { foundation managed to improve the livelihoods of farmers by } \\
\text { planting } 10 \text { different species of productive trees, including the } \\
\text { forest-dependent sugar palm. }\end{array}$ \\
\hline
\end{tabular}

Although Ecosia has a large number of social improvement projects, it is not the only initiative that has been started for these purposes. There have been various other projects that use search engines for environmental improvement and global sustainability, as can be seen in Table 5 .

Table 5 shows the distribution of the socially responsible search engines market as shown in the research of Schmidt et al. [18].

Table 5. Projects similar to Ecosia.

\begin{tabular}{ccccc}
\hline Name & URL & Since & Partners & Commitment \\
\hline Benefind (2010) & Benefind.de & 2009 & Yahoo, Bing & $\begin{array}{c}\text { Donation of 0.5 Euro per search query } \\
\text { to charitable purposes }\end{array}$ \\
\hline $\begin{array}{c}\text { Blackle-Heap } \\
\text { Media (2010) }\end{array}$ & Blackle.com & 2010 & Google & $\begin{array}{c}\text { Energy saving Internet search with } \\
\text { black background }\end{array}$ \\
\hline Echocho (2010) & Echocho.eu & 2008 & Yahoo & Purchase of $\mathrm{CO}_{2}$ certificates \\
\hline Ecosia (2010) & Ecosia.org & 2009 & Yahoo, Bing & $\begin{array}{c}\text { Donation of } 80 \% \text { of all revenues to } \\
\text { the WWF }\end{array}$ \\
\hline Forestle (2010) & Forestle.de & 2008 & Yahoo & $\begin{array}{c}\text { Donation of } 9 \% \text { of all revenue to the } \\
\text { group The Nature Conservancy }\end{array}$ \\
\hline GoodSearch (2010) & Goodsearch.com & 2005 & Yahoo & $\begin{array}{c}\text { Donation of 50\% of profits to } \\
\text { charitable purposes }\end{array}$ \\
\hline Treeho (2010) & Treehoo.com & 2008 & Yahoo & $\begin{array}{c}\text { Donation of } 50 \% \text { of profits to Tress for } \\
\text { the Future to plant trees }\end{array}$ \\
\hline Znout (2010) & Znout.org & 2008 & Google & Purchase of CO COn $_{2}$ certificates \\
\hline
\end{tabular}




\subsection{Unified Theory of Acceptance and Use of Technology}

Technology Acceptance Model (TAM) is a theoretical method that can be used to explain the impact of external factors on behavioral intention [21]. However, many of the variables have their own unique properties that are applicable in a wide range of fields, which resulted in the development of the integrated Unified Theory of Acceptance and Use of Technology (UTAUT) model [9]. The UTAUT model contains three constructs that have been recognized as decisive factors for behavioral intention: the expectation of performance, the expectation of effort, and social influence. The behavioral intention to use, together with the facilitating conditions constitutes two constructs of UTAUT and the TAM models that are considered decisive factors for the use behavior.

The UTAUT model is one of the most used by researchers to understand the choice and adoption of any technology [9]. This method unifies models such as the so-called Technology Acceptance Model (TAM) [21] as well as the well-known theory of Use Behavior [22]. Since its development, there have been numerous investigations which analyzed and expanded this theoretical perspective for academic research by adding different variants. The TAM model has been used in many studies that analyze the adoption of different technological variants, such as the adoption of cloud computing [23] or mobile applications $[1,10,24]$.

The research of Venkatesh and Davis [25] studies and presents the TAM 2 model. TAM 2 incorporates user satisfaction and technological acceptance into the model following the work of Wixom and Todd [26]. The TAM 3 model proposed by Venkatesh and Bala [27] specializes in Internet and electronic commerce.

In addition, the model has also been adapted to different research objectives in different organizations in order to understand, for example, the factors that influence the acceptance of use of ICT (Information and Communications Technology) by employees. This model is concerned with different perspectives, not only those of consumers as in the UTAUT model.

The UTAUT model has successfully been used in numerous studies, including projects involving various health-related technologies [28], robotics [29], procurement recommendation systems [30], booking systems in rural tourism [31], energy efficiency [32], and technologies for social innovation [33]. The UTAUT model has also increased its relevance in recent decades due to the fact that numerous investigations have developed the model in the area of innovation and adaptation of ICT [34].

In this research, the adoption of the Ecosia.org search engine is studied to extend research that uses the UTAUT model for ICT.

In the research presented by Venkatesh et al. [35], the UTAUT model explained 70\% of the variance in technology for the behavioral intention to use. This model has also been used to research areas such as the adoption of information systems by mobile banking technology users [5,36]. The model has also been applied to studies based on technologies that use the Internet, such as electronic commerce [37], web development and design [2], mobile telephony technologies [37], mobile applications [38], banking and electronic banking systems $[39,40]$, payment using mobile applications [41,42], education based on online devices [43], location-based services such as search engines [44,45], health services [46], the negotiation of actions based on technology [47], health and fitness applications [48], integrated instant messaging and social networking platforms or social search engines [49], smart watches [50], and e-tourism strategies and their visibility on the Internet [51].

In this research, the original UTAUT2 model was modified with additional variables in order to achieve the research objectives of the research. In UTAUT2, the use of technology is directly determined by the intention to use and facilitating conditions, as in UTAUT, but UTAUT2 adds the habit variable. The behavioral intention to use directly explains the expectation of performance, the expectation of effort and social influence, and, as a new addition, the hedonistic motivation and the price value. The relationships between the seven variables (the original four of UTAUT and the three additional ones of UTAUT2) and the behavioral intention to use and the behavioral use of technology are moderated by age, sex, and experience. In comparison with the original UTAUT model, the new UTAUT2 model [10] produced a substantial improvement in the explained variance of the behavioral intention to use (from $56 \%$ to $74 \%$ ) and the behavioral use of technology (from $40 \%$ to $52 \%$ ). 
This study sought to determine the benefits that users identified when using the Ecosia.org search engine and the factors that affect the use behavior as references to guide the future improvement of the search engine. Similarly, a comparison of the use of Ecosia.org with the use of the Google search engine, which is the most used search engine, was made.

As mentioned above, in this research we adapted the UTAUT2 model [10], a model that imports and develops efficient improvements into the original UTAUT model, in order to explain the behavioral intention to use a given search engine when users perform a search on Internet.

\subsection{Variables and Hypotheses Development}

The TAM model presents the relationship that exists between the expectation of utility and expectation of effort, that is supported by authors such as Escobar-Rodríguez and Carvajal-Trujillo [51] or Brown and Venkatesh [52] who define the perceived utility as the degree to which the use of a website helps consumers to carry out activities, in our case with the Ecosia.org search engine. Based on this definition, we establish the relationship between the perceived utility and the expectation of effort that consumers or users have with the use of the search engine. Other authors also formulate these hypotheses in similar studies based on ICT [35,43,50,53].

In the conclusions of different investigations, like those of [54,55] or [56], the results explain that consumers or users find the technology easy to use (lower expectation of effort). Users also believe that technology is useful (greater expectation of utility) and, therefore, the expectation of effort is similar to the Utility perceived in TAM [34].

In UTAUT, the effort expectation positively affects the acceptance of use [34]. The expectation of effort is defined by Venkatesh et al. [9] as the ease associated with the use of technology by users of ICT-based services. This value is related to the quality of the expected results shown by Internet search engines in [54-56].

Based on the statements made above, it is proposed that:

Hypothesis 1. The Effort Expectancy of the search engine performance has a positive effect on the Behavioral Intention to Use the search engine.

In this document, we study the trust in the access to information on the Internet with the use of search engines. That is, the trust that users have in search engines as tools to find information on the Internet, especially as information providers resulting from the searches may charge a fee in some cases.

Firstly, Trust refers to how much a user believes in the safety, reliability, efficiency, competence, and validity of a system that can be unsafe to use [41,56-59]. When users find a service to be unreliable, they tend to have less interaction with that service and related parties [56]. In the behavioral intention of use a search engine, Trust is defined as the general belief that these searches will be made [57].

This variable has been investigated in several studies on the Internet where the UTAUT model has been applied $[41,58]$. Therefore, we can structure the hypotheses in the following way:

Hypothesis 2. The Trust perceived by users who use the search engine on the Internet has a positive effect on the Behavioral Intention to Use.

Hypothesis 3. The Trust perceived by users of the Internet search engine has a positive effect on Use Behavior when using a search engine.

The relationship of the influence of Behavioral Intention to Use was defined by Venkatesh et al. and Venkatesh and Davis $[9,25]$. Other studies that consider the adoption of search engines define this structure as Planned Behavior [59]. Use Behavior has been established in different technology adoption models such as TAM [20] and UTAUT [34]. It is well known that the number of search engines on the Internet is increasing exponentially, as is the number of users who make queries on 
them $[41,44]$. The formulation of these hypotheses allows us to study the adoption behavior for the search engines by users and empirically demonstrates the relationship between Behavioral Intention to Use search engines and the Use Behavior for search engines. Previous studies $[4,30,35,59-62]$ have defined the Behavioral Intention to Use search engines as the attitude, beliefs, and perceptions of a person about using a technology, and the Use Behavior as the actual use that a user makes of the technology. In research by Liaw [59], the Behavioral Intention to Use is applied to the study of search engines.

Other authors also formulate these hypotheses in similar studies on the behavior and actions of a user with Internet search engines [57,58].

Based on the statements made above, it is proposed that:

Hypothesis 4. The Behavioral Intention to Use has a positive effect on the Use Behavior of the search engine.

The relationship between Social Influences on the use of search engines and the perceived usefulness of the search engine itself is another existing relationship. Social influence is defined in the research of Orso et al. [60] and is identified as the extent to which consumers believe that other important members in their lives, such as family members, friends, and other colleagues, believe that they should use a particular technology. Studies have been made on the relationship between the influence that this generates in use behavior when using one search engine or another $[26,51]$. However, the strongest social influences are the reasons why consumers perceive technology as more useful, influencing intention to use [34] and determining the option of adopting a new product [59]. These facts are studied by Orso et al. [60] for search engines.

Other authors also formulate these hypotheses in similar studies [35,44,63]. Following this line of thought and the investigations that confirm it, we constructed the fifth hypothesis:

Hypothesis 5. The Social Influence has a positive effect on the Behavioral Intention to Use for the search engine.

One of the new variables that UTAUT2 incorporates is the hedonic motivation, known in other studies as perceived enjoyment [51]. This new variable for the UTAUT2 model has a significant influence on the final behavioral intention to use [51]. Numerous investigations on the adoption of information systems demonstrate the influence of hedonic motivation on the behavioral intention to use a technology and the use behavior $[64,65]$. Therefore, the following hypothesis is presented:

Hypothesis 6. The Hedonic Motivation to use a search engine has a positive effect on the Behavioral Intention to Use the search engine.

Habit is considered the measure in which people perform actions automatically, doing so as a consequence of their learning $[9,64]$. It is a new variable in the UTAUT2 model and has been used in various investigations as a predictor for behavioral intention to use $[47,60,64,66]$ and has been shown to have a decisive influence on it. As a result, we consider that:

Hypothesis 7. The Habit of using the search engine has a positive effect on Behavioral Intention to Use for the search engine.

Hypothesis 8. The Habit of using the search engine has a positive effect on Use Behavior.

The facilitating conditions are the consumers' feelings about the resources and the support available to use it $[34,67]$. These variables were declared in the original UTAUT model and it has been possible to measure them in this study, because the users in this survey use search engines to obtain information and have previous experience with the search engines: 
Hypothesis 9. The Facilitating Conditions have a positive effect on the Behavioral Intention to Use the search engine.

Hypothesis 10. The Facilitating Conditions have a positive effect on the Use Behavior of the search engine.

As we have mentioned previously, price value is considered to be the relationship between the perceived benefits from using the search engine and the monetary cost of using it $[15,68]$. This is a new variable in the UTAUT2 model, which has already been studied in some recent research on ICT products and services $[53,69]$. This variable compares the cost or monetary price of the services that a particular technology ICT provides with the perceived quality of the service. This, from its original adaptation $[9,70]$, examines whether the perceived benefits of use of technology in some way exceed the financial expense of using the technology.

Hypothesis 11. The price value has a positive effect on the Behavioral Intention to Use the search engine.

Hypothesis 12. The price value has a positive effect on the Use Behavior of the search engine.

Based on the above12 hypotheses, this study presents a complete model (Figure 3) shown below.

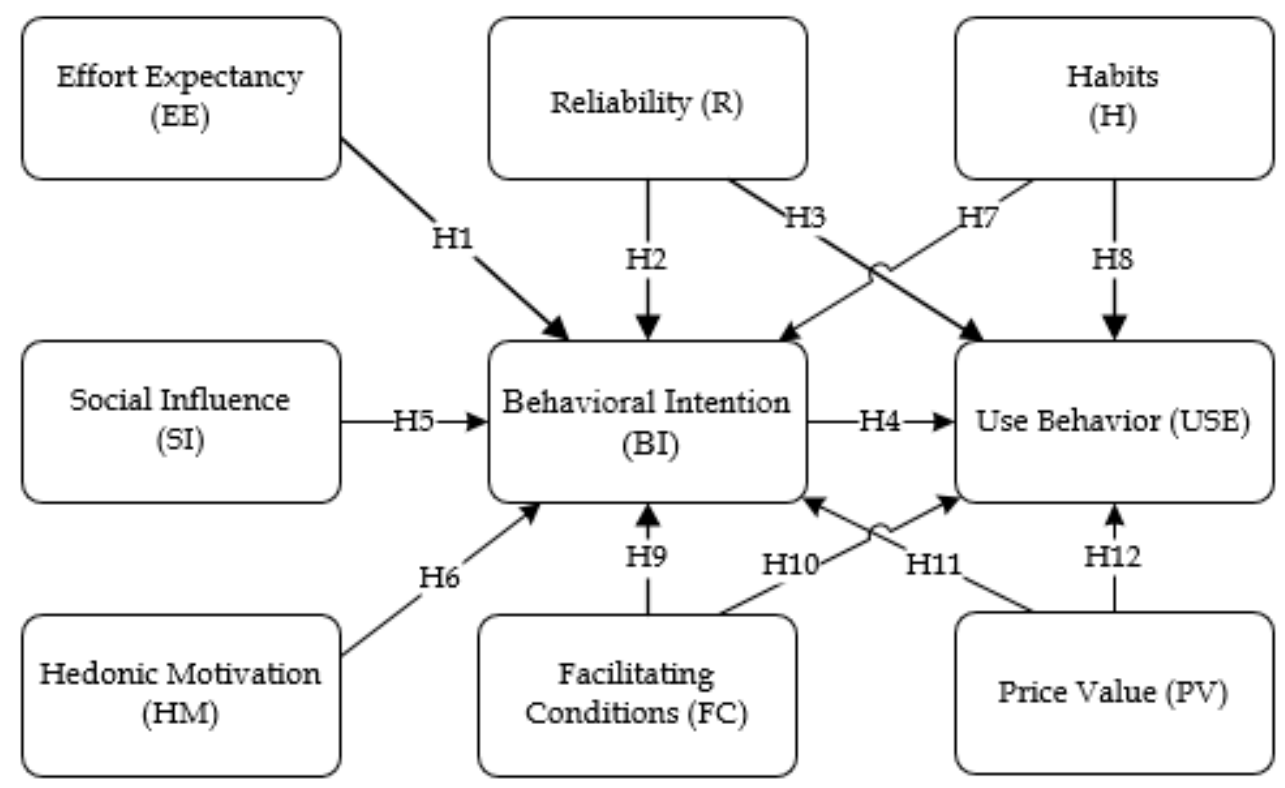

Figure 3. Proposed structural model.

\section{Research Data}

\subsection{Characteristics of Data Collection}

A total of 483 questionnaires were collected, of which 445 were finally found to be valid. The acceptance rate was $92.13 \%$. The results in Table 6 show the descriptive statistics of the sample members [71,72].

The largest group was women, who represented $56.8 \%$ of the sample, while men were $41.6 \%$ and others $1.6 \%$. The largest age group was for $18-30$ years, at $81.3 \%$, and the least numerous individuals were over 65 years with $0.2 \%$. Most of the participants had a university education (73.0\%), followed by Basic Studies (17.3\%) and Vocational Training/Baccalaureate (8.7\%). 
Table 6. Demographic Characteristics of the Sample.

\begin{tabular}{|c|c|c|c|}
\hline \multicolumn{2}{|c|}{ Classifications Variable } & \multirow{2}{*}{$\begin{array}{c}\text { Frequency } \\
253\end{array}$} & \multirow{2}{*}{$\begin{array}{c}\text { Percentage } \\
56.85 \%\end{array}$} \\
\hline \multirow{3}{*}{ Gender } & Female & & \\
\hline & Male & 185 & $41.58 \%$ \\
\hline & Others & 7 & $1.57 \%$ \\
\hline \multirow{5}{*}{ Age } & $18-30$ & 362 & $81.35 \%$ \\
\hline & $31-45$ & 49 & $11.01 \%$ \\
\hline & $46-55$ & 27 & $6.07 \%$ \\
\hline & $56-65$ & 6 & $1.35 \%$ \\
\hline & $>65$ & 1 & $0.22 \%$ \\
\hline \multirow{6}{*}{ Job } & Unemployed worker & 14 & $3.15 \%$ \\
\hline & Self-employed worker & 24 & $5.39 \%$ \\
\hline & Contracted worker & 58 & $13.03 \%$ \\
\hline & Student & 335 & $75.28 \%$ \\
\hline & Housewife & 8 & $1.80 \%$ \\
\hline & Retired & 6 & $1.35 \%$ \\
\hline \multirow{3}{*}{ Habitat } & Town with more than 100,000 inhabitants & 142 & $31.91 \%$ \\
\hline & From 20,000 to 100,000 habitants & 154 & $34.61 \%$ \\
\hline & Less than 20,000 habitants & 149 & $33.48 \%$ \\
\hline \multirow{3}{*}{ Level of education } & Basic Studies (O-levels) & 78 & $17.53 \%$ \\
\hline & Professional Training/A-levels & 42 & $9.44 \%$ \\
\hline & University Degree & 325 & $73.03 \%$ \\
\hline \multirow{4}{*}{$\begin{array}{l}\text { Access to Internet from } \\
\text { (multiple response) }\end{array}$} & Smartphone & 406 & $91.24 \%$ \\
\hline & Tablet or iPad & 117 & $26.29 \%$ \\
\hline & Laptop & 270 & $60.67 \%$ \\
\hline & Personal computer & 47 & $10.56 \%$ \\
\hline
\end{tabular}

The rest of the characteristics about occupation or Internet access device can also be seen in Table 6 . Some questions that were raised were about the search engines the users knew, the ones that they usually used, and which search engines were their favorites [73,74]. The frequencies and percentages of the answers to these questions are summarized in Table 7.

Table 7. Search Engine Characteristics.

\begin{tabular}{ccccc}
\hline \multirow{2}{*}{ Search Engine } & \multicolumn{2}{c}{ Favorite } & \multicolumn{2}{c}{ Used } \\
\cline { 2 - 5 } & Frequency & Percentage & Frequency & Percentage \\
\hline Google & 325 & $73.0 \%$ & 439 & $98.6 \%$ \\
Ecosia & 114 & $25.6 \%$ & 47 & $10.6 \%$ \\
Bing & 2 & $0.4 \%$ & 19 & $4.3 \%$ \\
Yahoo & 1 & $0.2 \%$ & 32 & $7.2 \%$ \\
Others & 3 & $0.7 \%$ & 10 & $2.2 \%$ \\
\hline
\end{tabular}

\subsection{Common Method Variance (CMV) Analysis}

After data collection, the Harman single factor test was used as a post hoc control measure of the common method bias [75,76]. Using this technique, the variables were included in an exploratory factorial analysis (EFA) and the non-rotated factorial solution was examined to determine if the variance in the data can be mainly attributed to any single factor [77].

Firstly, the 28 questions that addressed the nine constructs (i.e., Behavioral Intention to Use, Facilitating Conditions, Effort Expectancy, Habits, Hedonic Motivation, Price Value, Social Influence, Trust, and Use Behavior) were used to calculate the EFA. Factors that had an Eigen value of more than 1 were extracted; however, they could not explain most of the total variance, which suggests that any bias is unlikely. 


\subsection{Measurement}

Before answering the questionnaire, the users watched a 1-minute explanatory video about Ecosia, inserted into the online questionnaire. The purpose was to allow anyone who was unaware of the search engine to familiarize themselves with it. Next, users were asked to try the Ecosia search engine before answering the questionnaire. Five qualifying questions (gender, age, habitat, educational level, and employment situation) and three nominal questions were used. These were about the use of search engines and Internet (Internet access device, favorite search engines, and use of search engines). A total of 28 questions were answered using Likert five-point scales with 1 ("totally disagree") to 5 ("totally agree") and were grouped into the nine constructs previously mentioned. As an effective qualification method, the five-point Likert scale method is used to indicate the degree of importance of the factors [3]. These questions allowed for the final application of an explanatory analysis associated with subsample comparisons based on different classification variables.

The sample, as already noted, was composed of $n=445$ individuals. All of them claimed to use the Internet on average $2.5 \mathrm{~h}$ a day and use a search engine at least twice a week, which indicated that they had a lot of knowledge and experience using search engines and that they were therefore advanced Internet users, who have been defined [61-63] as users who use the Internet and search engines as sources of information on a regular basis and who are characterized by having skills that give them a positive predisposition for using technology. The field work was supported by the Spanish Association of Digital Natives, who sent its associates and those who are involved in its social activities to participate in it. The field work covered the period between May and October 2017. As the sample is composed of associate members and participants in the activities of the Association, we can see that the sampling procedure was not probabilistic, but discretionary sampling. Discretionary sampling consists of going to experts in the field to help in the determination of a representative sample [77]. To do this, the questionnaire was sent by email to 2150 individuals who met these requirements. A total of 483 were answered (22.46\%), of which 445 questionnaires were valid (20.70\%).

The Partial Least Squares (PLS) technique was applied for the estimation of structural equation models (SEMs, Structural Equations Models) based on variance. This technique was used to check the hypotheses in the proposed conceptual model. PLS is more appropriate when the objective is predicting and investigating relatively new phenomena [78] such as a search engine like Ecosia.org, which helps reduce deforestation. For the analysis of the structural model, Smart PLS 3 software was used $[79,80]$. Smart PLS 3 was chosen for its ability to graphically analyze the model and also for the range of statistical methods applied.

\section{Data Analysis}

\subsection{Individual Reliability of an Item}

The reliability of an item is evaluated by examining the loads $(\lambda)$ or simple correlations of the measures or indicators with their respective construct. The loads explain the variance shared between the construct and its indicators. This must be greater than the variance due to the error. A load value standard of $\lambda \geq 0.707$ was established by Luo et al. [69]; this condition was fulfilled for all the variables or items of each construct (see Table 8). 
Table 8. Loads $(\lambda)$ of the measures or indicators.

\begin{tabular}{|c|c|c|c|c|c|c|c|c|c|}
\hline Items & BI & FC & $\mathrm{EE}$ & $\mathrm{H}$ & HM & PR & $\mathbf{R}$ & SI & USE \\
\hline (FC1) & & 0.879 & & & & & & & \\
\hline (FC2) & & 0.867 & & & & & & & \\
\hline (FC3) & & 0.900 & & & & & & & \\
\hline (EE1) & & & 0.794 & & & & & & \\
\hline (EE2) & & & 0.834 & & & & & & \\
\hline (EE3) & & & 0.850 & & & & & & \\
\hline (EE4) & & & 0.819 & & & & & & \\
\hline (H1) & & & & 0.833 & & & & & \\
\hline (H3) & & & & 0.826 & & & & & \\
\hline (H4) & & & & 0.801 & & & & & \\
\hline (HM1) & & & & & 0.883 & & & & \\
\hline (HM2) & & & & & 0.899 & & & & \\
\hline (HM3) & & & & & 0.856 & & & & \\
\hline (SS1) & & & & & & & & 0.944 & \\
\hline (SS2) & & & & & & & & 0.953 & \\
\hline (SS3) & & & & & & & & 0.946 & \\
\hline (BI1) & 0.883 & & & & & & & & \\
\hline (BI2) & 0.896 & & & & & & & & \\
\hline (USE1) & & & & & & & & & 0.891 \\
\hline (USE2) & & & & & & & & & 0.826 \\
\hline (PR1) & & & & & & 0.869 & & & \\
\hline (PR2) & & & & & & 0.906 & & & \\
\hline (PR3) & & & & & & 0.829 & & & \\
\hline (R1) & & & & & & & 0.898 & & \\
\hline (R2) & & & & & & & 0.899 & & \\
\hline (R3) & & & & & & & 0.858 & & \\
\hline
\end{tabular}

\subsection{Reliability and Validity}

To examine the consistency of a construct, Cronbach's alpha and its composite reliability (CR, Composite Reliability) were used. These measure the consistency of a construct due to its indicators [81] - that is, the rigor with which these items are measuring the same latent variable. The lower limit for acceptance of the reliability of the construct is usually set at a Cronbach's alpha between 0.6 and 0.7 [82]. Other authors [83] state that internal consistency is confirmed if Cronbach's $\alpha$ is $>0.7$. Table 9 shows the calculation of the Cronbach's alpha coefficient for all of the constructs in the model. As can be seen, all the constructs have values much higher than Cronbach $\alpha>0.7$, which confirms the high internal consistency of all the latent variables.

Table 9. Internal consistency and convergent validity analyses.

\begin{tabular}{cccc}
\hline Construct & Cronbach's $\alpha$ & Composite Reliability & AVE (Average Variance Extracted) \\
\hline Behavioral Intention (BI) & 0.736 & 0.883 & 0.791 \\
Facilitating Conditions (FC) & 0.858 & 0.913 & 0.778 \\
Effort Expectancy (EE) & 0.844 & 0.895 & 0.680 \\
Habits (H) & 0.756 & 0.860 & 0.672 \\
Hedonics Motivation (HM) & 0.854 & 0.911 & 0.773 \\
Price Value (PR) & 0.838 & 0.902 & 0.755 \\
Social Influence (SI) & 0.944 & 0.964 & 0.898 \\
Trust (T) & 0.862 & 0.916 & 0.783 \\
Use Behavior (USE) & 0.702 & 0.849 & 0.738 \\
\hline
\end{tabular}

The convergent validity was studied with another statistic. Composite Reliability (CR) was used to evaluate internal consistency [63]. CR uses the load of indicators to analyze causality. As can be seen in Table 9, the calculation of composite reliability confirms once again that all constructs have 
high internal consistency, as shown by the values between 0.913 and 0.849 . Therefore, they are much higher than the minimum required level of 0.7 [81].

To assess convergent validity, we analyzed whether the indicators for a construct were significant and highly correlated, measured the same thing, and represented a single underlying construct. To evaluate the convergent validity, Fornell and Larcker [84] suggests the use of the average variance extracted (AVE), which gives information on how much variance a construct shows due to the indicators in relation to the quantity of variance due to measurement error [84]. The recommendation of these authors is that AVE $\geq 0.50$, which we can interpret as more than $50 \%$ of the variance of the construct being due to its indicators. The results obtained (see Table 9) support the convergent validity of the reflective constructs. As can be seen, all values exceeded 0.50, oscillating between 0.898 and 0.680. All the constructs, therefore fulfill this condition.

An analysis of the discriminate validity was made, using the criteria of Fornell and Larcker [84], who argued that if the correlation coefficient of two constructs was smaller than the square roots of the AVE of each construct, the discriminate validity between these constructs is confirmed. All the study data gave values complying with this rule, showing favorable discriminate validity for the constructs (see Table 10).

Table 10. Discriminant validity analysis.

\begin{tabular}{cccccccccc}
\hline Items & BI & FC & EE & H & HM & PR & SI & T & USE \\
\hline Behavioral Intention & 0.889 & & & & & & & & \\
Facilitating Conditions & 0.426 & 0.882 & & & & & & & \\
Effort Expectancy & 0.437 & 0.643 & 0.825 & & & & & & \\
Habits & 0.545 & 0.534 & 0.460 & 0.820 & & & & & \\
Hedonics Motivation & 0.515 & 0.307 & 0.331 & 0.434 & 0.879 & & & & \\
Price Value & 0.367 & 0.169 & 0.248 & 0.317 & 0.555 & 0.869 & & & \\
Social Influence & 0.159 & 0.046 & 0.038 & 0.140 & 0.247 & 0.398 & 0.948 & & \\
Trust & 0.431 & 0.312 & 0.327 & 0.388 & 0.597 & 0.589 & 0.247 & 0.885 & \\
Use Behavior & 0.728 & 0.421 & 0.400 & 0.514 & 0.488 & 0.412 & 0.185 & 0.454 & 0.859 \\
\hline
\end{tabular}

\subsection{Structural Equation Modeling}

Once an analysis of the measurement model for adequate levels of reliability and validity has been made, the next stage consists of the analysis of approximate adjustment measures of the model [85,86]). The discrepancies between the correlation matrix implied by the model and the empirical correlation matrix were measured. To do this, the Standardized Root Mean Square Residual (SRMR) was calculated $[87,88]$. This statistic measures the difference between the calculated correlations matrix and the implied correlations matrix of the model, reflecting the average magnitude of these differences. Thus, a model has a good fit when SRMR $<0.08$ [88]. For our model, the SRMR of the estimated model was 0.060 . Therefore, we can say that it has a good fit.

We also measured the predictive capacity of the model. The basic measure to determine the predictability of endogenous variables is $R^{2}$, which can be defined as the amount of variance of the construct explained by the model. When analyzing the predictive power of the model in terms of the variance, $\mathrm{Hu}$ and Bentler $[88,89]$ consider values for $R^{2}$ of $0.67,0.33$, and 0.19 to be, respectively, strong, moderate, and weak. As is logical, the latent variables of the model that are not endogenous have no $R^{2}$ value. This is the case of the independent variables Facilitating Conditions, Effort Expectancy, Habits, Hedonic Motivation, Price Value, Social Influence, and Trust [88,90-92].

Figure 4 shows the values of $R^{2}$ of all the endogenous variables. As can be seen, all values far exceed the minimum threshold of 0.1 , which confirms the predictive value of the model [79]. According to Nofer et al. [67], the $R^{2}$ value for Behavioral Intention to Use (0.428) and Use Behavior (0.573) can be considered moderate to strong. In short, although there may obviously be additional factors, we can say that the model has a high predictive level and a substantial part of the variance of the variables is explained by it $[84,85]$. 


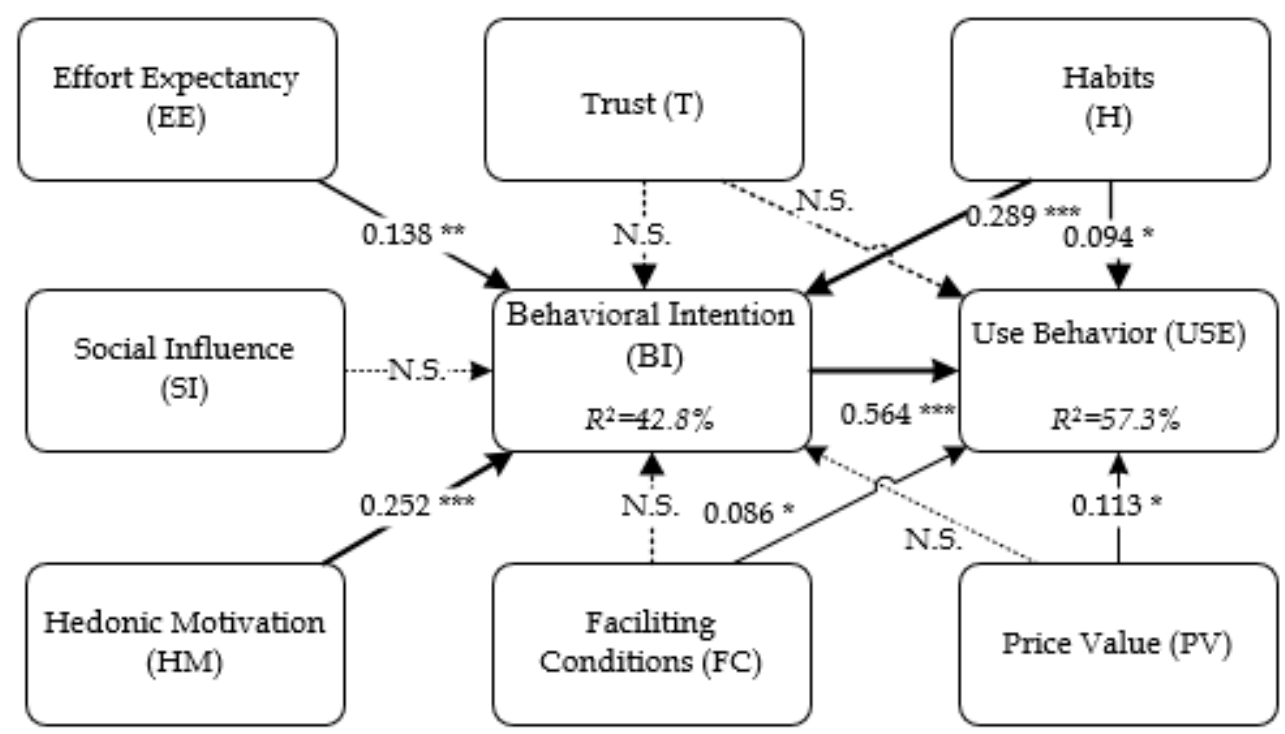

Figure 4. Results of structural equation modeling. ${ }^{*} p<0.05 ;{ }^{* *} p<0.01 ;{ }^{* * *} p<0.001$; N.S: Not supported.

\subsection{Model and Hypothesis Testing}

At this stage, the hypotheses will be tested to see if the relationships established between the different constructs in the proposed model are confirmed [89-92].

First, we must say that the constructs that have been found to have a significant impact on the Behavioral Intention to Use the search engine are: Effort Expectancy (H1), which in terms of significance reaches $99 \%(\beta=0.138 ; t=2.852)$; Hedonic Motivation $(\mathrm{H} 6)$, which in terms of significance reaches $99.9 \%(\beta=0.252 ; t=3.978)$; and Habits $(\mathrm{H7})$, which in terms of significance reaches $99.9 \%$ $(\beta=0.289, t=4.946)$.

The constructs that turned out to have a positive influence on the Use Behavior of the search engine were: Behavioral Intention to Use (H4), which in terms of significance reaches $99.9 \%(\beta=0.564$; $t=12.409)$; Habits (H8), which in terms of significance reaches $95 \%(\beta=0.094, t=1.957)$; Facilitating Conditions (H10), which in terms of significance reaches $95 \%(\beta=0.086 ; t=1.993)$; and Price Value (H12), which in terms of significance reaches $95 \%(\beta=0.113 ; t=2.457)$.

On the other hand, with respect to the model proposed by UTAUT2: the positive influence between the Social Influence and the Behavioral Intention to Use in H5 $(\beta=0.013 ; t=0.336)$, the positive influence between Facilitating Conditions and the Behavioral Intention to Use in H9 $(\beta=0.076 ; t=1392)$, and the positive influence between Price Value and Behavioral Intention to Use in H11 $(\beta=0.041 ; t=0.735)$ were not supported.

Considering the external Trust construct, which was added to the original model UTAUT2, none of the hypotheses were met. The positive influences between Trust and Behavioral Intention to Use (H2) $(\beta=0.072 ; t=1.207)$ and Trust and Use Behavior $(\mathrm{H} 3)(\beta=0.081 ; t=1.647)$ were not significant, so this variable does not seem to be significantly accepted in the proposed model. This means that confidence does not influence use behavior or the behavioral intention to use (see Table 11 and Figure 4). 
Table 11. Path coefficients and statistical significance.

\begin{tabular}{|c|c|c|c|c|c|}
\hline & Hypothesis & Coef. Path & Statistic $\mathbf{t}$ & $p$-Value & Result \\
\hline 1 & Effort Expectancy $\rightarrow$ Behavioral Intention to Use & 0.138 & 2.852 & 0.004 & Supported ${ }^{* *}$ \\
\hline 2 & Trust $\rightarrow$ Behavioral Intention to Use & 0.072 & 1.207 & 0.227 & Not supported \\
\hline 3 & Trust $\rightarrow$ Use Behavior & 0.081 & 1.647 & 0.100 & Not supported \\
\hline 4 & Behavioral Intention to Use $\rightarrow$ Use Behavior & 0.564 & 12.409 & 0.000 & Supported $* * *$ \\
\hline 5 & Social Influence $\rightarrow$ Behavioral Intention to Use & 0.013 & 0.336 & 0.737 & Not supported \\
\hline 6 & Hedonic Motivation $\rightarrow$ Behavioral Intention to Use & 0.252 & 3.978 & 0.000 & Supported *** \\
\hline 7 & Habits $\rightarrow$ Behavioral Intention to Use & 0.289 & 4.946 & 0.000 & Supported $* * *$ \\
\hline 8 & Habits $\rightarrow$ Use Behavior & 0.094 & 1.957 & 0.050 & Supported * \\
\hline 9 & Facilitating Conditions $\rightarrow$ Behavioral Intention to Use & 0.076 & 1.392 & 0.164 & Not supported \\
\hline 10 & Facilitating Conditions $\rightarrow$ Use Behavior & 0.086 & 1.993 & 0.046 & Supported * \\
\hline 11 & Price Value $\rightarrow$ Behavioral Intention to Use & 0.041 & 0.735 & 0.463 & Not supported \\
\hline 12 & Price Value $\rightarrow$ Use Behavior & 0.113 & 2.457 & 0.014 & Supported * \\
\hline
\end{tabular}

However, after carrying out a multi-group analysis (see Table 12) and comparing the hypotheses for the results obtained for users who marked Ecosia as a favorite and those who marked Google, the results differ in some hypotheses (see $p$-values in bold).

It can be seen that if Google is exclusively analyzed, there are significant differences in the influence of Trust on Use Behavior (H3) ( $p$-value google $=0.050$ ), whereas this hypothesis is met in the case of users who marked Google as a favorite. This means that Ecosia users do not take this variable into account, but they do for Google. Finally, the behavior of users is different in Google for H10 ( $p$-value Google $=0.174$, where the Facilitating Conditions do not positively influence Use Behavior. This would mean that for using Google these kinds of variables are not taken into account. However, they are important for the use of other search engines.

Very interesting results emerge from the exclusive analysis of Ecosia. The influence of Effort Expectancy on Behavioral Intention to Use $(\mathrm{H} 1)(p$-value Ecosia $=0.864)$ is significant (see bold), unlike with other search engines. The choice of Ecosia is not influenced by factors such as ease or difficulty of learning. This means that to use Ecosia, users do not take the expected effort into account. However, they do take this into account when using Google. This leads us to conclude that there are other additional motivations in the case of Ecosia, while Effort Expectancy is not significant. Other hypotheses change their statistical significance, as, for example, Hedonic Motivation, which does not positively nor significantly influence Behavioral Intention to Use $(\mathrm{H} 6)(p$-value Ecosia $=0.064)$. Therefore, this fact, which does not occur for the other search engines, indicates that enjoyment and entertainment are not taken into account when Ecosia is chosen as a favorite search engine. Finally, Price Value does not positively nor significantly influence Use Behavior (H12) ( $p$-value Ecosia $=0.912$ ), which indicates that the choice of Ecosia is not influenced by the price but by other factors.

Finally, a comparison of the results obtained from the different hypotheses in the sample and from the two sub-samples for the chosen search engine can be seen in Table 13. We can verify that the results obtained from the sample are similar to those obtained from the Google sample. 
Table 12. Path coefficients and statistical significance (Ecosia vs. Google).

\begin{tabular}{|c|c|c|c|c|c|c|c|}
\hline & Hypothesis & $\beta$ Ecosia & $\beta$ Google & Statistic $\mathbf{t}$ Ecosia & Statistic t Google & $p$-Value Ecosia & $p$-Value Google \\
\hline 1 & Effort Expectancy $\rightarrow$ Behavioral Intention to Use & 0.022 & 0.144 & 0.171 & 2.680 & 0.864 & 0.007 \\
\hline 2 & Trust $\rightarrow$ Behavioral Intention to Use & 0.020 & 0.115 & 0.137 & 1.720 & 0.891 & 0.085 \\
\hline 3 & Trust $\rightarrow$ Use Behavior & 0.022 & 0.105 & 0.173 & 1.894 & 0.863 & 0.050 \\
\hline 4 & Behavioral Intention to Use $\rightarrow$ Use Behavior & 0.503 & 0.568 & 3.519 & 11.720 & 0.000 & 0.000 \\
\hline 5 & Social Influence $\rightarrow$ Behavioral Intention to Use & 0.112 & -0.015 & 1.086 & 0.342 & 0.277 & 0.732 \\
\hline 6 & Hedonic Motivation $\rightarrow$ Behavioral Intention to Use & 0.257 & 0.261 & 1.853 & 3.838 & 0.064 & 0.000 \\
\hline 7 & Habits $\rightarrow$ Behavioral Intention to Use & 0.426 & 0.265 & 3.114 & 4.299 & 0.002 & 0.000 \\
\hline 8 & Habits $\rightarrow$ Use Behavior & 0.037 & 0.097 & 0.251 & 1.861 & 0.802 & 0.063 \\
\hline 9 & Facilitating Conditions $\rightarrow$ Behavioral Intention to Use & 0.068 & 0.095 & 0.476 & 1.615 & 0.634 & 0.106 \\
\hline 10 & Facilitating Conditions $\rightarrow$ Use Behavior & 0.285 & 0.063 & 2.146 & 1.359 & 0.032 & 0.174 \\
\hline 11 & Price Value $\rightarrow$ Behavioral Intention to Use & 0.116 & 0.000 & 1.025 & 0.008 & 0.306 & 0.994 \\
\hline 12 & Price Value $\rightarrow$ Use Behavior & 0.015 & 0.117 & 0.110 & 2.300 & 0.912 & 0.021 \\
\hline
\end{tabular}

Table 13. Comparison of the hypothesis testing results for the whole sample and the two sub-samples.

\begin{tabular}{|c|c|c|c|c|c|}
\hline & Hypothesis & $p$-Value Ecosia & $p$-Value Google & $p$-Value Search Engines & Result Search Engines \\
\hline 1 & Effort Expectancy $\rightarrow$ Behavioral Intention to Use & 0.864 & 0.007 & 0.004 & Supported ** \\
\hline 2 & Trust $\rightarrow$ Behavioral Intention to Use & 0.891 & 0.085 & 0.227 & Not supported \\
\hline 3 & Trust $\rightarrow$ Use Behavior & 0.863 & 0.050 & 0.100 & Not supported \\
\hline 4 & Behavioral Intention to Use $\rightarrow$ Use Behavior & 0.000 & 0.000 & 0.000 & Supported $* * *$ \\
\hline 5 & Social Influence $\rightarrow$ Behavioral Intention to Use & 0.277 & 0.732 & 0.737 & Not supported \\
\hline 6 & Hedonic Motivation $\rightarrow$ Behavioral Intention to Use & 0.064 & 0.000 & 0.000 & Supported $* * *$ \\
\hline 7 & Habits $\rightarrow$ Behavioral Intention to Use & 0.002 & 0.000 & 0.000 & Supported $* * *$ \\
\hline 8 & Habits $\rightarrow$ Use Behavior & 0.802 & 0.063 & 0.050 & Supported * \\
\hline 10 & Facilitating Conditions $\rightarrow$ Use Behavior & 0.032 & 0.174 & 0.046 & Supported * \\
\hline 11 & Price Value $\rightarrow$ Behavioral Intention to Use & 0.306 & 0.994 & 0.463 & Not supported \\
\hline 12 & Price Value $\rightarrow$ Use Behavior & 0.912 & 0.021 & 0.014 & Supported * \\
\hline
\end{tabular}

499) $=3.106644601$ ) 


\section{Conclusions}

This study explored the factors that affect the adoption of Ecosia.org. This was done using the second version of the Unified Theory of Acceptance and Use of Technology (UTAUT2) [9].

This study confirms the idea that an Internet search engine that helps mitigate the effects of climate change by planting trees is well received by Internet users. This conclusion is supported by the fact that $25.6 \%$ (see Table 6) of the sample members indicated Ecosia.org as a favorite. However, in this same sample, the individuals who regularly use the search engine fell to $10.6 \%$, which indicates that preference and use are not totally related $[93,94]$.

The results obtained offer an optimistic outlook for the fight against deforestation, and consequently against climate change, by showing an interest of consumers for the responsible consumption of resources. The case that was studied in this research study offers a future in which companies are responsible for the environmental consequences of their actions, and where consumers can, with their choice of service, choose to what extent they are willing to contribute to the deterioration of the planet. Therefore, environmental management will start to not only be the responsibility of countries and governments, but of us all $[95,96]$.

We saw how the Behavioral Intention to Use influences Use Behavior (H4) for users of search engines other than Ecosia.org, which is perceived as a socially responsible search engine that helps improve the environment. From this hypothesis, we can see that users are fully aware of the characteristics of search engines and the effects of using each one. Search engine users are therefore able to assess the different characteristics of each search engine and the actions and options which are available with each one. This fact confirms that the users understand the reasons for Ecosia.org and its social business model.

Another important result is that Social Influence does not influence Behavioral Intention to Use (H5) for any particular search engine. Therefore, although 21st century society is concerned about the state of the planet, pollution, and global warming, it is still not a problem or social concern that society links with projects whose ultimate goal is to contribute to the improvement of sustainability and global warming.

This study helps to demonstrate that habit is very powerful and that it has a decisive influence on Behavioral Intention to Use (H7) and Use Behavior (H8) [61-63,97,98]. Many questionnaires reflect this in the answers given, where the subjects indicate that they do not consider changing the search engine they use, amongst other reasons, because they always automatically use the same one. Such solid consumption habits have been formed that it is difficult for users to modify their chosen search engine when making queries on the Internet, even though the new option offers social values that strongly support the environment.

We must bear in mind that respect for the environment is also related to habit and the questions that are continually asked are "Which habit is most powerful?", "Can a search engine really break that habit?" The results indicate, however, that few users accept the idea of changing their habits and prefer to continue with the traditional search engine because the added value presented by a browser that supports the environment with its social tasks is not enough to de-link the habit of using a preferred search engine. It is therefore striking that the generations that use search engines daily to find information are not willing to change their habits for causes that fight against worsening global warming, the ozone layer, air quality, or the general pollution of the planet. It is surprising to see how the society of the XXI century, which is advanced and worried, a priori, about the planet is not willing to modify its habits when consulting the Internet for the mere fact of having to use a different search engine. The positive environmental actions of a search engine are not influential enough to change the users' choice of a habitually used search engine.

Even though users may understand the Facilitation Conditions for a search engine, this fact does not influence the Behavioral Intention to Use it, which is the reason why H9 is rejected. However, the influence of Facilitating Conditions on Use Behavior (H10) is confirmed. This is because search engine users understand and feel that the Facilitating Conditions will allow them to perform specific 
tasks when using a search engine to make inquiries on the Internet. In this respect, the interface of Ecosia.org is very similar to the rest of search engines on the Internet, so the design and easily usable interface is an important factor that influences the Use Behavior of search engine users on the Internet. However, for the choice of one particular search engine or another, certain variables such as the Price Value do not influence the Behavioral Intention to Use (H11) of search engine users, because accessing the internet with a search engine is considered such a basic and necessary task that it has become a habit in their daily life.

However, Ecosia is seen to be a widely compatible search engine that does not need many resources to use it, since the influence of Effort Expectancy is not significant in Behavioral Intention to Use (H1). This conclusion makes us optimistic and gives Ecosia.org a competitive advantage over its competitors.

This research work discovers two additional advantages. On the one hand, users relate Price Value with Use Behavior (H12), but not in the case of Ecosia.org, where the influence is not significant. That is to say, in the case of Ecosia.org, users do not mind what the company that owns the search engine does with its income, but they are concerned about this for the rest of the companies. In these other cases, the users could demand more improvements or a more correct distribution of income. This fact does not occur in Ecosia.org, which distributes up to $80 \%$ of its income in the planting of trees in areas of need on our planet.

It is very interesting to discover that Behavioral Intention to Use is conditioned in a very significant way by Hedonic Motivation (H6). That is, enjoyment, use of search engines in leisure time, or as entertainment, are all reasons that condition behavior. However, this does not happen in Ecosia.org. Unlike other search engines, this factor does not condition user behavior. It seems therefore that environmental respect and, above all, the contribution to the end of deforestation and mistreatment of our forests is a more important priority than enjoyment or entertainment when choosing a particular search engine as a favorite.

This study confirms that ecological marketing is an appropriate marketing strategy for the future, which can increase the intention to use a technological product. Based on the results obtained, this study shows that a search engine or, perhaps in the future, another Internet service that is auditable (visits, searches, files, etc.) can also contribute to curbing the effects of deforestation and climate change. These conclusions are based on the fact that Trust is not a factor that conditions Use Behavior (H3) in the case of Ecosia.org. Therefore, we can affirm that the social business model established by Ecosia.org can be used by other forms of technology to improve the environment and the sustainability of the planet. In addition, companies and, especially technological start-ups, are recommended to take into account that users feel better using tools that support the environment, sustainability, or that fight against the effects of climate change, even though this fact does not ensure that users will use the product in question instead of the competition if this has already become a habit.

The results of this research for the importance of awareness and promotion of deforestation are solid. This means that the results of this research can be used to improve users' awareness of the problems of deforestation, climate change, and air pollution. Forestry deals with the management of woods and forests as well as the science of tree cultivation. The results of this research can help to improve the understanding of this science and show its importance for the preservation of the planet, the fight against climate change, and the reduction of air pollution, and, above all, can increase awareness of the massive felling of trees and the problems that this brings to the planet.

Therefore, the results of this investigation can be used to urge foundations and non-governmental organizations to support these initiatives, as well as suggest that the companies that provide technological services follow the ecological marketing strategy of Ecosia.org, because of the positive effects achieved on user satisfaction by using this strategy.

The use of services that support sustainability increases user satisfaction and in the medium and long term means that the decision to use is influenced by the added value which is provided by these types of business initiatives. Companies must include these types of initiatives into their objectives 
in order to contribute to the improvement of the planet and have effective ecological marketing. Companies must ensure that the environmentally aware products and services that they provide become a habit for the consumers.

The scope of the present study is limited to a survey carried out on a community of advanced Internet users with an online questionnaire regarding the behavior and use of search engines that included the unique, ecological search engine Ecosia.org. Therefore, future researchers are encouraged to extend the scope and duration of the study with different users in other geographical areas in order to achieve more conclusive results.

Acknowledgments: The authors thank the participants in the community for their assistance in collecting the data for this study.

Author Contributions: Jose R. Saura contributed to the study design, collected field data, and drafted the manuscript. Pedro R. Palos-Sanchez critically revised the manuscript and performed the statistical analysis and interpreted the results. Both authors conceived the study and contributed to the interpretation of the results.

Conflicts of Interest: The authors declare no conflict of interest.

\section{Appendix A}

Table A1. Questionnaire and Constructs (adopted to authors).

\begin{tabular}{|c|c|}
\hline $\begin{array}{l}\text { Facilitating conditions } \\
{[9,34,51]}\end{array}$ & $\begin{array}{l}\text { (CF1) I have the necessary resources to use an Internet search engine } \\
\text { (CF2) I have the necessary knowledge to use an Internet search engine } \\
\text { (CF3) My Internet search engine is compatible with the other technologies I use (Browser, Operating } \\
\text { System, etc.) }\end{array}$ \\
\hline $\begin{array}{l}\text { Effort Expectancy } \\
{[9,54-56]}\end{array}$ & $\begin{array}{l}\text { (EE1) Learning to use my Internet search engine is easy for me } \\
\text { (EE2) My interaction with the Internet search engine is clear } \\
\text { (EE3) I find my Internet search engine easy to use } \\
\text { (EE4) It is easy for me to be proficient in using my favorite Internet search engine }\end{array}$ \\
\hline Habit $[9,64]$ & $\begin{array}{l}\text { (H1) Using my Internet search engine could become a habit for me } \\
\text { (H3) Using my Internet search engine could become natural for me } \\
\text { (H4) Using my Internet search engine could become something I do without thinking }\end{array}$ \\
\hline $\begin{array}{l}\text { Hedonics Motivation } \\
{[9,64-67]}\end{array}$ & $\begin{array}{l}\text { (HM1) I enjoy using my Internet search engine } \\
\text { (HM2) When I use my search engine on the Internet I have fun } \\
\text { (HM3) Using my search engine on the Internet, in my free time, entertains me }\end{array}$ \\
\hline $\begin{array}{l}\text { Social Influence } \\
{[9,35,44,50]}\end{array}$ & $\begin{array}{l}\text { (SS1) The people that are important to me think that I should use my Internet search engine more } \\
\text { (SS2) The people that influence my behavior think that I should use my Internet search engine more } \\
\text { (SS3) People whose opinions I value think that I should use my Internet search engine more }\end{array}$ \\
\hline $\begin{array}{l}\text { Behavioral Intention } \\
\text { to Use }[9,57,58]\end{array}$ & $\begin{array}{l}\text { (BI1) I intend to use my Internet search engine in the future } \\
\text { (BI2) I will always try to use my Internet search engine in my day to day life }\end{array}$ \\
\hline Use Behavior $[9,57,58]$ & $\begin{array}{l}\text { (USE1) I plan to use my Internet search engine in the coming days } \\
\text { (USE2) I intend to recommend the use of my Internet search engine to other users }\end{array}$ \\
\hline Price Value $[9,15]$ & $\begin{array}{l}\text { (PR1) My Internet search engine correctly distributes its income } \\
\text { (PR2) My Internet search engine provides value with its activities } \\
\text { (PR3) I positively value the price of my Internet search engine ads }\end{array}$ \\
\hline Trust $[41,58]$ & $\begin{array}{l}\text { (R1) My Internet search engine is honest } \\
\text { (R2) My Internet search engine understands the users } \\
\text { (R3) My Internet search engine has good intentions }\end{array}$ \\
\hline
\end{tabular}

\section{References}

1. Agrebi, S.; Jallais, J. Explain the intention to use smartphones for mobile shopping. J. Retail. Consum. Serv. 2015, 22, 16-23. [CrossRef]

2. Al-Qeisi, K.; Dennis, C.; Alamanos, E.; Jayawardhena, C. Website design quality and usage behavior: Unified Theory of Acceptance and Use of Technology. J. Bus. Res. 2014, 67, 2282-2290. [CrossRef]

3. Allen, I.E.; Seaman, C.A. Likert scales and data analyses. Qual. Prog. 2007, 40, 64.

4. Bankole, F.O.; Bankole, O.O.; Brown, I. Mobile banking adoption in Nigeria. Electron. J. Inf. Syst. Dev. Ctries. 2011, 47, 1-23. [CrossRef] 
5. Baptista, G.; Oliveira, T. Understanding mobile banking: The unified theory of acceptance and use of technology combined with cultural moderators. Comput. Hum. Behav. 2015, 50, 418-430. [CrossRef]

6. Batet, M.; Sánchez, D. A Review on Semantic Similarity. In Encyclopedia of Information Science and Technology, 3rd ed.; IGI Global: Hershey, PA, USA, 2014; pp. 7575-7583.

7. Bollegala, D.; Matsuo, Y.; Ishizuka, M. A Relational Model of Semantic Similarity between Words using Automatically Extracted Lexical Pattern Clusters from the Web. In Proceedings of the Conference on Empirical Methods in Natural Language Processing, EMNLP, Singapore, 6-7 August 2009; ACL and AFNLP: Singapore, 2009; pp. 803-812.

8. NetMarket. Search Engine Market Share. Retrieved 1 October 2017. Available online: https://netmarketshare. com/search-engine-market-share.aspx?qprid=4\&qpcustomd=0 (accessed on 3 October 2017).

9. Venkatesh, V.; Thong, J.Y.; Xu, X. Consumer acceptance and use of information technology: Extending the unified theory of acceptance and use of technology. MIS Q. 2012, 36, 157-178.

10. Shaikh, A.A.; Karjaluoto, H. Mobile banking adoption: A literature review. Telemat. Inf. 2015, 32, $129-142$. [CrossRef]

11. Jayaram, D.; Manrai, A.K.; Manrai, L.A. Effective use of marketing technology in Eastern Europe: Web analytics, social media, customer analytics, digital campaigns and mobile applications. J. Econ. Financ. Adm. Sci. 2015, 20, 118-132. [CrossRef]

12. Kent, M.L.; Carr, B.J.; Husted, R.A.; Pop, R.A. Learning web analytics: A tool for strategic communication. Public Relat. Rev. 2011, 37, 536-543. [CrossRef]

13. Saura, J.R.; Palos-Sánchez, P.; Suárez, L.M. Understanding the Digital Marketing Environment with KPIs and Web Analytics. Future Internet 2017, 9, 76. [CrossRef]

14. Nabout, A.; Skiera, B.; Stepanchuk, T.; Gerstmeier, E. An analysis of the profitability of fee-based compensation plans for search engine marketing. Int. J. Res. Mark. 2012, 29, 68-80. [CrossRef]

15. Dodds, W.B.; Monroe, K.B.; Grewal, D. Effects of price, brand, and store information on buyers' product evaluations. J. Mark. Res. 1991, 28, 307-319. [CrossRef]

16. Chapelle, O.; Chang, Y. Yahoo! Learning to Rank Challenge Overview. In Proceedings of the 27th International Conference on Machine Learning (ICML 2010), Haifa, Israel, 26 August 2010; pp. 1-24.

17. Martínez-Sanahuja, L.; Sánchez, D. Evaluating the Suitability of Web Search Engines as Proxies for Knowledge Discovery from the Web. Procedia Comput. Sci. 2016, 96, 169-178. [CrossRef]

18. Schmidt, N.-H.; Ruch, T.J.; Decker, J.; Kolbe, L.M. Ecosia.org: The Business Case of a Green Search Engine. In Green Business Process Management; Vom Brocke, J., Seidel, S., Recker, J., Eds.; Springer: Berlin, Germany, 2010; pp. 217-232.

19. Lewandowski, D. Evaluating the retrieval effectiveness of Web search engines using a representative query sample. J. Assoc. Inf. Sci. Technol. 2015, 66, 1763-1775. [CrossRef]

20. Pernici, B.; Aiello, M.; vomBrocke, J.; Donnellan, B.; Gelenbe, E.; Kretsis, M. What IS can do for Environmental Sustainability: A Report from the CAiSE’11 Panel on Green and Sustainable IS. Commun. AIS 2012, 30, 18.

21. Davis, F.D.; Bagozzi, R.P.; Warshaw, P.R. User acceptance of computer technology: A comparison of two theoretical models. Manag. Sci. 1989, 35, 982-1003. [CrossRef]

22. Fishbein, M.; Ajzen, I. Belief, Attitude, Intention, and Behavior: An Introduction to Theory and Research; Addison-Wesley: Boston, MA, USA, 1975.

23. Palos-Sanchez, P.R. El cambio de las relaciones con el cliente a través de la adopción de APPS: Estudio de las variables de influencia en M-Commerce. Rev. ESPACIOS 2017, 38, 38.

24. Liébana-Cabanillas, F.; Sánchez-Fernández, J.; Muñoz-Leiva, F. Antecedents of the adoption of the new mobile payment systems: The moderating effect of age. Comput. Hum. Behav. 2014, 35, 464-478. [CrossRef]

25. Venkatesh, V.; Davis, F.D. A theoretical extension of the technology acceptance model: Four longitudinal field studies. Manag. Sci. 2000, 46, 186-204. [CrossRef]

26. Wixom, B.H.; Todd, P.A. A theoretical integration of user satisfaction and technology acceptance. Inf. Syst. Res. 2005, 16, 85-102. [CrossRef]

27. Venkatesh, V.; Bala, H. Technology acceptance model 3 and a research agenda on interventions. Decis. Sci. 2008, 39, 273-315. [CrossRef]

28. Hsieh, H.L.; Kuo, Y.M.; Wang, S.R.; Chuang, B.K.; Tsai, C.H. A Study of Personal Health Record User's Behavioral Model Based on the PMT and UTAUT Integrative Perspective. Int. J. Environ. Res. Public Health 2016, 14, 8. [CrossRef] [PubMed] 
29. Wolbring, G.; Diep, L.; Yumakulov, S.; Ball, N.; Yergens, D. Social robots, brain machine interfaces and neuro/cognitive enhancers: Three emerging science and technology products through the lens of technology acceptance theories, models and frameworks. Technologies 2013, 1, 3-25. [CrossRef]

30. Wang, Y.Y.; Luse, A.; Townsend, A.M.; Mennecke, B.E. Understanding the moderating roles of types of recommender systems and products on customer behavioral intention to use recommender systems. Inf. Syst. e-Bus. Manag. 2015, 13, 769-799. [CrossRef]

31. San Martín, H.; Herrero, Á. Influence of the user's psychological factors on the online purchase intention in rural tourism: Integrating innovativeness to the UTAUT framework. Tour. Manag. 2012, 33, 341-350. [CrossRef]

32. Khorasanizadeh, H.; Honarpour, A.; Park, M.S.A.; Parkkinen, J.; Parthiban, R. Adoption factors of cleaner production technology in a developing country: Energy efficient lighting in Malaysia. J. Clean. Prod. 2016, 131, 97-106. [CrossRef]

33. Casey, T.; Wilson-Evered, E. Predicting uptake of technology innovations in online family dispute resolution services: An application and extension of the UTAUT. Comput. Hum. Behav. 2012, 28, 2034-2045. [CrossRef]

34. Williams, M.D.; Rana, N.P.; Dwivedi, Y.K.; Lal, B. Is UTAUT really used or just cited for the sake of it? A systematic review of citations of UTAUT's originating article. In Proceedings of the 19th European Conference on Information Systems, Helsinki, Finland, 9-11 June 2011.

35. Venkatesh, V.; Morris, M.G.; Davis, G.B.; Davis, F.D. User acceptance of information technology: Toward a unified view. MIS Qual. 2003, 27, 425-478. [CrossRef]

36. Yu, C. Factors affecting individuals to adopt mobile banking: Empirical evidence from the UTAUT model. J. Electron. Commer. Res. 2012, 13, 104-121.

37. Uzoka, F.M.E. Organisational influences on e-commerce adoption in a developing country context using UTAUT. Int. J. Bus. Inf. Syst. 2008, 3, 300-316. [CrossRef]

38. Ma, Q.; Chan, A.H.; Chen, K. Personal and other factors affecting acceptance of smartphone technology by older Chinese adults. Appl. Ergon. 2016, 54, 62-71. [CrossRef] [PubMed]

39. Palos-Sanchez, P.R.; Arenas-Marquez, F.J.; Aguayo-Camacho, M. Cloud Computing (SaaS) adoption as a strategic technology: Results of an empirical study. Mob. Inf. Syst. 2017. [CrossRef]

40. Khan, I.U.; Hameed, Z.; Khan, S.U. Understanding Online Banking Adoption in a Developing Country: UTAUT2 with Cultural Moderators. J. Glob. Inf. Manag. 2017, 25, 43-65. [CrossRef]

41. Zhou, T. An empirical examination of continuance intention of mobile payment services. Decis. Support Syst. 2013, 54, 1085-1091. [CrossRef]

42. Zhou, T. Understanding mobile Internet continuance usage from the perspectives of UTAUT and flow. Inf. Dev. 2011, 27, 207-218. [CrossRef]

43. Zhou, T. Examining location-based services usage from the perspectives of unified theory of acceptance and use of technology and privacy risk. J. Electron. Commer. Res. 2012, 13, 135.

44. Shorfuzzaman, M.; Alhussein, M. Modeling Learners' Readiness to Adopt Mobile Learning: A Perspective from a GCC Higher Education Institution. Mob. Inf. Syst. 2016. [CrossRef]

45. Yun, H.; Han, D.; Lee, C.C. Understanding the use of location-based service applications: Do privacy concerns matter? J. Electron. Commer. Res. 2013, 14, 215.

46. Sun, Y.; Wang, N.; Guo, X.; Peng, Z. Understanding the acceptance of mobile health services: A comparison and integration of alternative models. J. Electron. Commer. Res. 2013, 14, 183.

47. Tai, Y.-M.; Ku, Y.-C. Will stock investors use mobile stock trading? A benefit-risk assessment based on a modified UTAUT model. J. Electron. Commer. Res. 2013, 14, 67.

48. Yuan, S.; Ma, W.; Kanthawala, S.; Peng, W. Keep using my health apps: Discover users' perception of health and fitness apps with the UTAUT2 model. Telemed. e-Health 2015, 21, 735-741. [CrossRef] [PubMed]

49. Lai, I.K.W.; Guicheng, S. The impact of privacy concerns on the intention for continued use of an integrated mobile instant messaging and social network platform. Int. J. Mob. Commun. 2015, 13, 641-669. [CrossRef]

50. Cho, I.; Park, H. The influential factors on the diffusion of smartwatches in Korea. Int. J. Technol. Manag. 2016, 72, 230-251. [CrossRef]

51. Escobar-Rodríguez, T.; Carvajal-Trujillo, E. Online purchasing tickets for low cost carriers: An Application of the unified theory of acceptance and use of technology (UTAUT) model. Tour. Manag. 2014, 43, 70-88. [CrossRef] 
52. Brown, S.A.; Venkatesh, V. Model of adoption of technology in households: A baseline model test and extension incorporating household life cycle. MIS Q. 2005, 29, 399-426. [CrossRef]

53. Bruner, G.C.; Kumar, A. Explaining consumer acceptance of handheld Internet devices. J. Bus. Res. 2005, 58, 553-558. [CrossRef]

54. Ghobrial, G.M.; Mehdi, A.; Maltenfort, M.; Sharan, A.D.; Harrop, J.S. Variability of patient spine education by Internet search engine. Clin. Neurol. Neurosurg. 2014, 118, 59-64. [CrossRef] [PubMed]

55. Ma, Z.; Sheng, O.R.; Pant, G.; Iriberri, A. Can visible cues in search results indicate vendors reliability? Decis. Support Syst. 2012, 52, 768-775. [CrossRef]

56. Shenker, B.S. The accuracy of Internet search engines to predict diagnoses from symptoms can be assessed with a validated scoring system. Int. J. Med. Inf. 2014, 83, 131-139. [CrossRef] [PubMed]

57. Chaffey, D.; Patron, M. From web analytics to digital marketing optimization: Increasing the commercial value of digital analytics. J. Direct Data Digit. Mark. Pract. 2012, 14, 30-45. [CrossRef]

58. Dotson, J.P.; Fan, R.R.; Feit, E.M.; Oldham, J.D.; Yeh, Y. Brand Attitudes and Search Engine Queries. J. Interact. Mark. 2017, 37, 105-116. [CrossRef]

59. Liaw, S. The theory of planned behaviour applied to search engines as a learning tool. J. Comput. Assist. Learn. 2004, 20, 283-291. [CrossRef]

60. Orso, V.; Ruotsalo, T.; Leino, J.; Gamberini, L.; Jacucci, G. Overlaying social information: The effects on users' search and information-selection behavior. Inf. Process. Manag. 2017, 53, 1269-1286. [CrossRef]

61. Hendahewa, C.; Shah, C. Evaluating user search trails in exploratory search tasks. Inf. Process. Manag. 2017, 53, 905-922. [CrossRef]

62. Chau, M.; Wong, C.H. Designing the user interface and functions of a search engine development tool. Decis. Support Syst. 2010, 48, 369-382. [CrossRef]

63. Antoniou, D.; Plegas, Y.; Tsakalidis, A.; Tzimas, G.; Viennas, E. Dynamic refinement of search engines results utilizing the user intervention. J. Syst. Softw. 2012, 85, 1577-1587. [CrossRef]

64. Hew, J.J.; Lee, V.H.; Ooi, K.B.; Wei, J. What catalyses mobile apps usage intention: An empirical analysis. Ind. Manag. Data Syst. 2015, 115, 1269-1291. [CrossRef]

65. Chang, S.E.; Shen, W.C.; Liu, A.Y. Why mobile users trust smartphone social networking services? A PLS-SEM approach. J. Bus. Res. 2016, 69, 4890-4895. [CrossRef]

66. Jang, Y.T.; Chang, S.E.; Tsai, Y. Smartphone security: Understanding smartphone users' trust in information security management. Secur. Commun. Netw. 2014, 7, 1313-1321. [CrossRef]

67. Nofer, M.; Hinz, O.; Muntermann, J.; Roßnagel, H. The economic impact of privacy violations and security breaches. Bus. Inf. Syst. Eng. 2014, 6, 339-348. [CrossRef]

68. Gefen, D.; Straub, D.; Boudreau, M.C. Structural equation modeling and regression: Guidelines for research practice. Commun. Assoc. Inf. Syst. 2000, 4, 1e70.

69. Luo, X.; Li, H.; Zhang, J.; Shim, J.P. Examining multi-dimensional trust and multi-faceted risk in initial acceptance of emerging technologies: An empirical study of mobile banking services. Decis. Support Syst. 2010, 49, 222-234. [CrossRef]

70. Delre, S.A.; Jager, W.; Bijmolt, T.H.; Janssen, M.A. Will it spread or not? The effects of social influences and network topology on innovation diffusion. J. Prod. Innov. Manag. 2010, 27, 267-282. [CrossRef]

71. Van Der Heijden, H. User acceptance of hedonic information systems. MIS Q. 2004, 28, 695-704. [CrossRef]

72. Viejo, A.; Sánchez, D.; Castellà-Roca, J. Preventing automatic user profiling in Web 2.0 applications. Knowl.-Based Syst. 2012, 36, 191-205. [CrossRef]

73. Watson, R.T.; Boudreau, M.-C.; Chen, A.J. Information systems and environmentally sustainable development: Energy informatics and new directions for the IS community. MIS Q. 2010, 34, 23-38. [CrossRef]

74. Werts, C.E.; Linn, R.L.; Jöreskog, K.G. Quantifying Unmeasured Variables: Measurement in the Social Sciences; Aldine: Chicago, IL, USA, 1974; pp. 270-292.

75. Limayem, M.; Hirt, S.G.; Cheung, C.M. How habit limits the predictive power of intention: The case of information systems continuance. MIS Q. 2007, 31, 705-737. [CrossRef]

76. Kim, S.S.; Malhotra, N.K. Predicting system usage from intention and past use: Scale issues in the predictors. Decis. Sci. 2005, 36, 187-196. [CrossRef]

77. Bui, H.T.; Baruch, Y. Learning organizations in higher education: An empirical evaluation within an international context. Manag. Learn. 2012, 43, 515-544. [CrossRef] 
78. Chin, W.W.; Newsted, P.R. Structural Equation Modeling Analysis with Small Samples Using Partial Least Squares. In Statistical Strategies for Small Sample Research; Hoyle, R., Ed.; Sage Publications: Thousand Oaks, CA, USA, 1999; pp. 307-341.

79. Ringle, C.M.; Wende, S.; Becker, J.M. SmartPLS 3. 2015 Boenningstedt: SmartPLS GmbH. Available online: http:/ /www.smartpls.com (accessed on 2 October 2017).

80. Carmines, E.G.; Zeller, R.A. Reliability and validity assessment. Sage publications CASE tools as organizational change: Investigating incremental and radical changes in systems development. MIS Q. 1979, 17, 309-340.

81. Götz, O.; Liehr-Gobbers, K.; Krafft, M. Evaluation of structural equation models using the Partial Least Squares (PLS) approach. In Handbook of Partial Least Squares; Chin, W.W., Esposito Vinzi, V., Eds.; Springer: Berlin, Germany, 2010; pp. 691-711.

82. Hair, J.; Black, W.; Babin, B.; Anderson, R.; Tatham, R. Multivariate Data Analysis, 5th ed.; Prentice Hall: Upper Saddle River, NJ, USA, 2005.

83. Guilford, J. Fundamental Statistics in Psychology and Education, 4th ed.; McGraw-Hill: New York, NY, USA, 1965.

84. Fornell, C.; Larcker, D.F. Evaluating structural equation models with unobservable variables and measurement error. J. Mark. Res. 1981, 18, 39-50. [CrossRef]

85. Henseler, J. Adanco 2.0.1. User Manual; Composite Modeling GmbH \& Co.: Kleve, Germany, 2017.

86. Henseler, J.; Hubona, G.; Ray, P.A. Using PLS path modeling in new technology research: Updated guidelines. Ind. Manag. Data Syst. 2016, 116, 2-20. [CrossRef]

87. Hu, L.; Bentler, P.M. Fit indices in covariance structure analysis: Sensitivity to under parameterized model misspecification. Psychol. Methods 1998, 3, 424-453. [CrossRef]

88. Hu, L.; Bentler, P.M. Cutoff criteria for fit indexes in covariance structure analysis: Conventional criteria versus new alternatives. Struct. Equ. Model. 1999, 6, 1-55. [CrossRef]

89. Chin, W.W. The partial least squares approach to structural equation modeling. Mod. Methods Bus. Res. 1998, 295, 295-336.

90. Falk, R.; Miller, N. A Primer for Soft Modeling; University of Akron Press: Akron, OH, USA, 1992.

91. Satoh, K.; Yamana, H. Hit Count Reliability: How Much Can We Trust Hit Counts? In Proceedings of the 14th Asia-Pacific International Conference on Web Technologies and Applications, Kunming, China, 11-13 April 2012; pp. 751-758.

92. Schaltegger, S.; Zvezdov, D. Expanding material flow cost accounting. Framework, review and potentials. J. Clean. Prod. 2015, 108, 1333-1341. [CrossRef]

93. Tesauro, G.; Gondek, D.C.; Lenchner, J.; Fan, J.; Prager, J.M. Analysis of Watson's strategies for playing Jeopardy! J. Artif. Intell. Res. 2013, 47, 205-251.

94. Trespalacios Gutiérrez, J.A.; Vázquez Casielles, R.; Ballina Ballina, F.J.D.L.; Suárez Vázquez, A. Investigación de Mercados: El Valor de los Estudios de Mercado en la era del Marketing Digital; Paraninfo, S.A., Ed.; Repositorio de la Universidad de Oviedo: Madrid, Spain, 2016; 262p, ISBN 978-84-2833-852-3.

95. Bruin, T.; Rosemann, M. Using the Delphi technique to identify BPM capability areas. In Proceedings of the 18th Australasian Conference on Information Systems, Toowoomba, Australia, 5-7 December 2007.

96. Briggs, R.O.; de Vreede, G.-J.; Nunamaker, J.F., Jr. Collaboration engineering with think Lets to pursue sustained success with group support systems. J. Manag. Inf. Syst. 2003, 19, 31-64.

97. Cilibrasi, R.L.; Vitányi, P.M.B. The Google Similarity Distance. IEEE Trans. Knowl. Data Eng. 2006, 19, 370-383. [CrossRef]

98. Davenport, T.H. Mission Critical: Realizing the Promise of Enterprise Systems; Harvard Business School Press: Boston, MA, USA, 2000.

(C) 2018 by the authors. Licensee MDPI, Basel, Switzerland. This article is an open access article distributed under the terms and conditions of the Creative Commons Attribution (CC BY) license (http:/ / creativecommons.org/licenses/by/4.0/). 